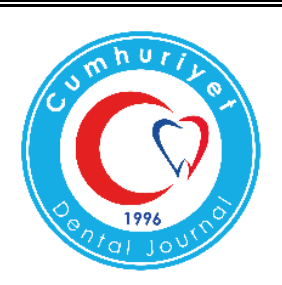

\title{
EVALUATION OF CAFFEIC ACID PHENETHYL ESTER ADMINISTRATION IN CHRONICALLY STRESSED RATS WITH EXPERIMENTAL PERIODONTITIS
}

\begin{abstract}
Objectives: The aim of the present study was to investigate the therapeutic effects of systemic caffeic acid phenethyl ester treatment on oxidative stress and alveolar bone destruction in lipopolysaccharide (LPS)-induced periodontitis (EP) group in chronically stressed rats.
\end{abstract}

Materials and Methods: Fourty male Sprague Dawley rats (EP-CS-CAPE) group were divided into four groups: 1) control group, 2) experimental periodontitis (EP), 3) EP and chronic stress (CS) group (EP-CS), and 4) EP-CS treated with CAPE (EP-CS-CAPE). To induce periodontitis, LPS was administered into the buccal gingiva of the test groups, and pure saline was administered for the interleukin (IL)$1 \beta$ levels were control group. Two test groups were exposed to restraint stress and one group of these groups was treated with only a single dose of CAPE (10 $\mathrm{mmol} / \mathrm{kg}$ ). Likewise, saline was administered in the control, EP, and EP-CS groups. After 14 days, serum samples were collected from the heart, and all rats were sacrificed for analyses. Oxidative stress and interleukin (IL)-1 $\beta$ were investigated. The receptor activator of the nuclear factor kappa B ligand (RANKL) and alveolar bone loss were determined by immunohistochemical analysis.

Results: The oxidative stress, alveolar bone loss, IL-1 $\beta$ and RANKL levels were found significantly higher in the EP-CS group compared with control and EP groups $(\mathrm{p}<0.05)$. However, the administration of RANKL level CAPE significantly reduced oxidative stress and IL- $1 \beta$ in the EP-CS-CAPE group compared with the EP-CS group ( $\mathrm{p}<0.05)$. Also, CAPE treatment significantly reduced RANKL and alveolar bone loss in the EP-CS-CAPE group compared with the EP-CS group $(\mathrm{p}<0.05)$.

Conclusions: The present results indicated that CAPE may inhibit alveolar bone loss by modulating the immune response and inflammatory process.

Keywords: Alveolar bone loss, antioxidants, periodontitis
*Alper Kızıldağ ${ }^{1}$

Daner Arabaci ${ }^{2}$

Mevlüt Albayrak ${ }^{3}$

DUfuk Taşdemir ${ }^{4}$

D) Mukaddes Mergen Dalyanoğlu ${ }^{5}$

(iDCanan Aksu Kızıldağ ${ }^{6}$

ORCID IDs of the authors:

A.K.0000-0002-1630-3140

T.A.0000-0003-0476-1010

M.A.0000-0001-8673-6577

U.T.0000-0002-0631-1665

M.M.D.0000-0002-5862-7792

C.A.K.0000-0002-2687-7551

1 Department of Periodontology, Faculty of Dentistry, Pamukkale University, Denizli, Turkey.

2 Department of Periodontology, Faculty of Dentistry, Atatürk University, Erzurum, Turkey.

${ }^{3}$ Medical Laboratory Department, Health Services Vocational Training School, Ataturk University, Erzurum, Turkey.

${ }^{4}$ Department of Maxillofacial Surgery, Faculty of Dentistry, Pamukkale University, Denizli, Turkey.

5 Department of Phsiology, Medical School,

Pamukkale University, Denizli, Turkey.

6 Department of Orthodontics, Faculty of Dentistry, Pamukkale University, Denizli, Turkey.

$\begin{array}{ll}\text { Received } & : 16.01 .2019 \\ \text { Accepted } & : 19.02 .2019\end{array}$

How to Cite: Kızıldağ A, Arabacı T, Albayrak M, Taşdemir U, Dalyanoğlu MM, Kızıldağ CA. Evaluation of Caffeic Acid Phenethyl Ester Administration in Chronically Stressed Rats with Experimental Periodontitis. Cumhuriyet Dent J 2019;22:1:114-120. 


\section{INTRODUCTION}

Inflammatory periodontitis leads to the destruction of tooth-supporting tissues and to alveolar bone loss. Factors including genetic predisposition, environmental factors, and the association between pathogenic bacteria and the host immune response increase the severity and progression of periodontitis. ${ }^{1}$ In recent years, psychologic factors, such as anxiety, stress, and depression, have been suggested as playing a critical role in periodontal disease. ${ }^{2,3}$ Studies have reported that stress accelerates alveolar bone resorption and periodontal attachment loss and impairs tissue wound healing. ${ }^{4,5}$

Stress can activate the hypothalamic-pituitaryadrenal (HPA) axis, and activation of the HPA axis stimulates glucocorticoid hormones from the adrenal cortex..$^{6-8}$ These corticoid hormones increase proinflammatory cytokines levels. ${ }^{9}$ Additionally, activation of the HPA axis elevates the brain corticosterone level, and this corticosterone stimulates the overproduction of glutamate in the cortical and limbic areas. ${ }^{10}$ The stimulation of glutamate release enhances the metabolic rate by disrupting mitochondrial activity. ${ }^{11}$ The increased metabolic rate causes breakdown of the balance between the anti-oxidant defense system and the reactive oxygen species (ROS) level by overproduction of free radicals. ${ }^{12}$ Furthermore, especially in chronic stress (CS)-depressed humans, the immune response is altered by reducing immunoglobulin $A$ and $G$, impairing neutrophil activity, and suppressing cytokine production. ${ }^{13}$

CAPE is an antioxidant and has antiinflammatory and antitumoral effects. ${ }^{14}$ Gremy et al. reported that CAPE regulated the immune response by preventing the apoptosis. ${ }^{15}$ Recent reports have suggested that CAPE improves tissue wound healing, avoids osteoclastogenesis by induced the receptor activator of the nuclear factor kappa B ligand (RANKL), decreases ROS and oxidative stress, and contributes to bone healing. ${ }^{14,16-21}$

Experimental studies have confirmed that stress increases the severity and progression of periodontal disease, and several agents have been advocated to prevent stress-induced periodontitis. ${ }^{22-24}$ However, data on the efficacy of CAPE in periodontitis with stressed animals are lacking. We hypothesized that administering CAPE on stressed rats may reduce alveolar bone loss and oxidative stress in periodontitis. Hence, the present study was designed to evaluate the effect of CAPE on experimental periodontitis with stressed rats.

\section{MATERIALS AND METHODS}

\section{Animals}

Fourty male Sprague Dawley rats (12 weeks of age) weighing approximately $250 \mathrm{~g}$ were used in the present study. All rats were housed five per cage at the ideal room temperature of $21^{\circ} \mathrm{C} \pm 2{ }^{\circ} \mathrm{C}$ with 12 -h light and dark cycle and were fed rat pellets and water ad libitum. The rats were assigned randomly to four groups as follows: control, rats with experimental periodontitis (EP), rats with EP and CS (EP-CS), and rats with EP-CS treated by CAPE (EPCS-CAPE). The experimental protocols were approved by Pamukkale University Ethics Committee for Animal Experimentation (PAUHADYEK-2017/07). Study procedures were applied at the Pamukkale University Laboratory of Experimental Animals Research Centre.

\section{Induction of Experimental Periodontitis}

Periodontitis was induced in rats by an lipopolysaccharide (LPS) procedure $(10 \mu \mathrm{L}$ Esherichia coli E, serotype 055: B5, L2637; Sigma Chemical Co., St. Louis, MO, USA; $1 \mathrm{mg} / \mathrm{mL}$ ). ${ }^{25-27}$ General anesthesia was performed with mixture solutions of xylazine $(10 \mathrm{mg} / \mathrm{kg})$ and ketamine (40 $\mathrm{mg} / \mathrm{kg}$ ). Under general anesthesia, an LPS solution was administered into the vestibular gingival sites between the upper right first and second maxillary molars. This procedure was applied every other day for five days. Pure saline was administered in the control animals using the same procedure.

\section{Protocol of Chronic Stress}

Restraint stress was applied according to a previous study $^{24}$, using a flexible plastic mesh $(30 \times 30 \mathrm{~cm})$, after which the rats were placed in plastic pipes (10 $\times 30 \mathrm{~cm}$ ) for 12 hours. These animals did not receive food or water during this period. Other groups were fed limited food and water (pair feeding), but the restraint procedure was not applied. All animals were returned to their cages at 
the end of the day. These protocols were performed daily for 15 days before LPS injection and 14 days after LPS injection.

\section{Antioxidant Treatment}

After the LPS injection, CAPE was administered intraperitoneally at a daily rate of $10 \mathrm{mmol} / \mathrm{kg}$ in the EP-CS-CAPE group during the last 14 days as previously described. ${ }^{19,21,28}$ The solution of CAPE was injected at the same time every day for standardization during the trials. Pure saline solutions were administered to the control, EP, and EP-CS groups using the same method.

\section{Sample Collection}

After the rats had been anesthetized intramuscularly, blood samples from the heart were collected via cardiac puncture, and the rats were decapitated. The blood samples were centrifuged at $2358 \mathrm{~g}$ for $10 \mathrm{~min}$ at $4^{\circ} \mathrm{C}$ to obtain serum. The serum samples were frozen at $-80^{\circ} \mathrm{C}$ for biochemical analyses. Additionally, the maxillae of all rats were removed and fixed in $10 \%$ neutral formaldehyde solution for histological evaluation to detect alveolar bone loss.

\section{Biochemical Assay}

Serum interleukin-1 $\beta$ (IL-1 $\beta$ ) concentrations were analyzed by rat-specific enzyme-linked immunoassay (ELISA) kit (Fine Biotechnology, Wuhan, China) according to the manufacturer's instructions.

Commercially available ELISA kits (Rel Assay Diagnostics, Gaziantep, Turkey) were used to evaluate the serum total antioxidant status (TAS) and serum total oxidant status (TOS) levels according to the manufacturer's recommended protocols. The results were stated as millimolar Trolox equivalent per liter (mmol Trolox Eq/L protein) for TAS. The results were also stated as micromolar hydrogen peroxide equivalent per liter (mmol H2O2 Eq/L protein) for TOS. In the present study, the oxidative stress index (OSI) was calculated as described in a previous study and expressed as the percentage ratio of TOS to TAS. ${ }^{29}$

\section{Histologic Procedures}

The fixed jaws $(10 \%$ neutral buffered formaldehyde) were decalcified with $6 \%$ nitric acid solution for 7 days. These maxillary tissues were stored at room temperature, and the nitric acid solution was replaced daily. At the end of this process, the decalcified tissues were kept in alcohol for dehydration and were embedded in paraffin buccolingually. Eight slides (5-mm thicknesses) were obtained for each rat by a microtome (Leica RM2125RT, Leica Instruments, Nubloch, Germany). The sections were stained using Crossman-modified Mallory triple and photographed by a light microscope with a camera attachment (Nikon Eclipse i50; Nikon, Tokyo, Japan). In the present study, the attachment level of the maxillary molars was determined by stereological analyses. The proportions of distal periodontal bone support (DPBS) and mesial periodontal bone support (MPBS) (\%) were evaluated using a triocular light microscope attached to analyzing software (Kameram SLR, 1.4.1.0, Mikro Sistem, Istanbul, Turkey). To analyze the bone support, the distance between the epithelial attachment and root apex was divided by the distance between the crown tip and root apex.

\section{Immunohistochemical Staining}

For immunohistochemical analyses, the tissue sections were stained using with anti-RANKL kit (1:50 dilution) (Santa Cruz Biotechnology, Santa Cruz, CA.) according to the manufacturer's protocols. The binding of antibodies was imaged with a high-power light microscope (Eclipse i50, Nikon, Tokyo, Japan.) to evaluate the immunopositive cell intensity. The stereologic optical fractionator method was applied to determine the numeric density values of RANKL- positive cells in 10 sections of alveolar bone for each animal. A stereology workstation, which consisted of stereology software (StereoInvestigator, v.9.0, Microbrightfield, Williston, VT.) and a modified light microscope (Leica DM4000B, Leica Instruments.), was used to perform the stereologic analyses. ${ }^{30}$

\section{Statistical Analysis}

All data had a normal distribution and the coefficient variation was less than $20 \%$. For this reason, one-way ANOVA and the Duncan post hoc test were used with statistical software (SPSS v.17.0, IBM, Chicago, IL.) to estimate the differences among the groups. The results are 
expressed as mean \pm SD for each group. $\mathrm{p}<0.05$ was considered significant.

\section{RESULTS}

The biochemical results for each group are shown in Table 1. The serum OSI level increased significantly in the EP group compared with the control group $(\mathrm{p}<0.05)$. However, the CAPE treatment significantly reduced the OSI level in the EP-CS-CAPE group compared with that of the EPCS group $(\mathrm{p}<0.05)$.

Table 1. Comparison of Immunohistochemical and Biochemical Results

\begin{tabular}{llllll}
\hline & MPBS $(\%)$ & DPBS $(\%)$ & IL-1 & OSI & RANKL \\
\hline Control & $59.63 \pm 6.18^{*}$ & $58.27 \pm 5.95^{*}$ & $60.12 \pm 7.13^{*}$ & $2.13 \pm 0.88^{*}$ & $0.0000431^{*}$ \\
EP & $48.79 \pm 4.51^{* *}$ & $49.33 \pm 4.92^{* *}$ & $89.94 \pm 8.35^{* *}$ & $9.39 \pm 2.40^{* *}$ & $0.0000619^{* *}$ \\
EP-CS & $39.41 \pm 3.76^{\#}$ & $38.17 \pm 3.62^{\#}$ & $115.52 \pm 12.82^{\#}$ & $21.59 \pm 5.61^{\#}$ & $0.0000825^{\#}$ \\
EP-CS-CAPE & $46.94 \pm 4.38^{* *}$ & $47.05 \pm 4.49^{* *}$ & $94.71 \pm 10.42^{* *}$ & $15.86 \pm 4.72^{\# \#}$ & $0.0000648^{* *}$ \\
\hline
\end{tabular}

Footnote: Values are expressed as mean \pm SD. Symbols $(*, *, \#, \ldots \#)$ in the same column indicate significant differences among groups; $p<0.05$.

The serum IL-1 $\beta$ level in the EP group was significantly higher than that in the control group $(\mathrm{p}<0.05)$. Furthermore, CAPE administration reduced the serum IL-1 $\beta$ level in the EP-CS-CAPE group significantly more than in the EP-CS group $(\mathrm{p}<0.05)$.

\section{Immunohistochemical results}

The level of the RANKL-positive osteoclastic cells was determined to be significantly higher in the test groups compared with the control group $(\mathrm{p}<0.05)$. The increase of the RANKL-positive osteoclastic cells was more significant in the EP-CS group than in the EP group $(p<0.05)$. CAPE treatment significantly reduced the level of RANKL-positive osteoclastic cells in the EP-CS-CAPE group compared with the EP-CS $(\mathrm{p}<0.05)$ (Table 1).

\section{Bone Support}

MPBS and DPBS was significantly lower in the disease groups compared with the control group $(p<0.05)$. MPBS and DPBS were significantly higher in the EP group compared with the EP-CS group $(\mathrm{p}<0.05)$. In addition, CAPE treatment significantly decreased the loss of MPBS and DPBS in the EP-CS-CAPE group compared with that in the EP-CS group $(\mathrm{p}<0.05)$ (Table 1).

\section{DISCUSSION}

Stress is one of the factors leading to periodontitis and the effects of stress on periodontal destruction have been established. ${ }^{24}$ In this study, alveolar bone loss was significantly higher in the EP-CS group than in the EP group, confirming that stress increases the severity of periodontitis. ${ }^{24,31}$ Different agents have been used to prevent alveolar bone loss caused by stress-induced periodontitis. ${ }^{22,23}$ However, to the best of our knowledge, this is the first study to evaluate the positive effects of CAPE on CS-induced periodontitis. Kazancioglu et al. ${ }^{19}$ showed that CAPE significantly increased bone healing in calvarial defects. In an another study, CAPE was reported to decrease alveolar bone loss significantly in experimental periodontitis. ${ }^{32}$ The present findings showed that CAPE significantly prevented alveolar bone loss in the EP-CS-CAPE group compared with the EP-CS group, and these results confirmed that CAPE reduces bone loss and enhances bone healing. ${ }^{19,32}$

RANKL controls bone formation by osteoclast cells activity and is associated with periodontal bone loss. ${ }^{33}$ In the present study, RANKL levels were significantly higher in the EP group than in the control group, confirming that periodontitis increases the RANKL level. ${ }^{30,33}$ In addition, stress can stimulate a rise in the RANKL level. Wang et $a l .{ }^{34}$ reported that stress causes myocardial injury by improving the RANKL level. Additionally, Peruzzo et $a l .{ }^{24}$ reported that CS elevates the RANKL level in periodontitis. Our results revealed that CS significantly increased the RANKL level, and these findings confirmed those of the previous studies. ${ }^{24,34}$ CAPE prevents osteoclastogenesis by decreasing the RANKL level. ${ }^{17}$ The results showed that the RANKL level was significantly lower in the EP-CSCAPE group than in the EP-CS group, and the present results in this study confirmed that CAPE 
may improve bone healing by reducing RANKLinduced osteoclast activity. ${ }^{17}$

Oxidative stress causes the destruction of periodontal tissues. OSI is defined by TOS/TAS status, and we used OSI to evaluate oxidative stress. A study reported that periodontitis significantly altered OSI levels by elevating the TOS level and reducing the TAS level. ${ }^{35}$ Similar to the previous study, the present results indicated that OSI was significantly higher in the EP group than in the control group. The CS can increase the OSI level by disturbing the balance of oxidant and antioxidant activity. Samarghandian et $a l .^{36}$ determined that CS increased oxidative markers and decreased antioxidant markers. Our findings indicated that CS significantly increased the OSI level in the EP-CS group compared with the EP group. The present results confirmed that CS increases the ROS level and oxidative markers. ${ }^{36,37}$ Antioxidant agents have been used to inhibit oxidative damage. A study reported that CAPE treatment significantly reduced oxidative stress in rats with periodontitis. ${ }^{32}$ In the present study, these findings show that CAPE treatment significantly decreased the OSI level in the EP-CS-CAPE group compared with the EP-CS group and these results are consistent with those of the previous study. ${ }^{32}$ The decrease in the OSI level may be related to CAPE preventing the activation of the HPA axis and decreasing the brain corticosterone levels.

Proinflammatory cytokines have a critical role in the inflammatory process and on bone loss. Serum IL- $1 \beta$ levels have been used to evaluate the severity of periodontitis. Agarwal et al. ${ }^{38}$ reported that LPS induces the secretion of IL-1 $\beta$. Kose et $a l .{ }^{39}$ indicated that periodontitis significantly elevated the serum IL-1 $\beta$ level in rats. The present findings showed that the serum IL- $1 \beta$ level was significantly higher in the EP group compared with the control group, and these findings are consistent with those of previous studies. ${ }^{38,39}$ Psychological factors can change the production and secretion of proinflammatory cytokines, especially IL-1. Gomes et l. $^{23}$ suggested that stress significantly increases the hippocampal IL-1 $\beta$ level in the brain; however, in the periodontium, they did not determine significantly different IL-1 $\beta$ levels in the stress-induced group compared with the control group. In another study, Peruzzo et al. ${ }^{24}$ suggested that CS significantly elevated proinflammatory cytokines in rats with EP. Data from the present study showed that CS significantly increased serum IL-1 $\beta$ levels in the EP-CS group compared with the EP group, and these results confirmed those of the previous study. ${ }^{24}$ In addition, CAPE treatment significantly decreased serum IL-1 $\beta$ levels in the EP-CS-CAPE group compared with the EP-CS group. CAPE has an anti-inflammatory effect and may modulate the expression of CS-induced proinflammatory cytokines.

\section{CONCLUSIONS}

Immunohistochemical and biochemical analyses showed that CS accelerates alveolar bone loss in periodontitis by stimulating the inflammatory response and oxidative stress. However, CAPE significantly prevented alveolar bone loss by reducing CS-induced RANKL, oxidative stress, and proinflammatory cytokines. The present study provided a new insight in terms of understanding effect of CS on periodontal destruction. Also, CAPE may supply antioxidant and anti-inflammatory agents to prevent the destructive effect of CS on periodontitis. However, additional studies are necessary to verify the present data and to investigate the role of other pathways in periodontitis after CS.

\section{ACKNOWLEDGEMENTS}

None.

\section{CONFLICTS OF INTEREST}

The authors declare that there are no conflicts of interest regarding the publication of this paper.

\section{Deneysel Periodontitis Oluşturulan Kronik Stresli Sıçanlarda Kafeik Asit Fenetil Ester (KAFE) Uygulamasının Değerlendirilmesi}

$\ddot{O} Z$

Amaç: Bu çalışmanın amacı sistemik kafeik asit fenetil ester (KAFE) uygulamasinın lipopolisakkarit (LPS) ile periodontitis oluşturulan kronik stresli sıçanlarda oksidatif stres ve alveolar kemik kaybı üzerine terapötik etkisinin değerlendirilmesidir. Gereç ve Yöntemler: Çalışmamızda 40 adet Sprague Dawley sıçan kullanıldı ve bu sıçanlar dört gruba ayrlldı: 1) kontrol grubu, 2) 
deneysel periodontitis (DP) grubu, 3) DP ve kronik stres (KS) grubu (DP-KS) ve 4) KAFE ile tedavi edilen DP$K S$ grup (DP-KS-KAFE). Periodontitis oluşturmak amacıla LPS test gruplarında bukkal dişetine uyguland ve aynı yöntemle kontrol grubuna salin verildi. Bununla birlikte test gruplarından ikisine kısitlama stresi uyguland ve bu gruplardan biri de günlük tek doz KAFE ile tedavi edildi (10 mmol/kg). Benzer şekilde kontrol ve interlökin (IL)-1 $\beta$ seviyeleri incelendi. DP ve DP-KS gruplarina da salin uyguland. 14 gün sonra, hayvanların kalbinden serum örnekleri toplandı ve bütün hayvanlar analiz için sakrifiye edildi. Oksidatif stres, interlökin (IL)-1 $\beta$ incelendi. Reseptör aktivatör nükleer faktör kappa B ligand (RANKL) ve alveolar kemik kaybı immünohistokimyasal olarak değerlendirildi. Bulgular: Oksidatif stres, alveoar kemik kaybl, IL-1 $\beta$ ve RANKL seviyeleri DP-KS grubunda kontrol ve DP gruplarına göre anlamlı bir şekilde yüksek bulundu $(p<0,05)$. Ancak, KAFE uygulamasl oksidatif stres ve $I L-1 \beta$ seviyelerini $D P-K S$ KAFE grubunda DP-KS grubuna göre anlaml olarak azalttı $(p<0,05)$. Bununla birlikte yine KAFE tedavisi RANKL ve alveolar kemik kaybını DP-KS-KAFE grubunda DP-KS grubuna göre anlaml olarak azalttı (p<0,05). Sonuçlar: Bu sonuçlar KAFE'nin immün cevabı ve enflamatuvar olayları düzenleyerek alveolar kemik kaybını önleyebileceğini göstermiştir. Anahtar Kelimeler: Alveolar kemik kaybu, antioksidanlar, periodontitis

\section{REFERENCES}

1. Slots J. Periodontology: past, present, perspectives. Periodontol 2000 2013;62:7-19.

2. Okoro CA, Strine TW, Eke PI, Dhingra SS, Balluz LS. The association between depression and anxiety and use of oral health services and tooth loss. Community Dent Oral Epidemiol 2012;40:134-144.

3. Rai B, Kaur J, Anand SC, Jacobs R. Salivary stress markers, stress, and periodontitis: a pilot study. J Periodontol 2011;82:287-292.

4. Gaspersic R, Stiblar-Martincic D, Skaleric U. Influence of restraint stress on ligature-induced periodontitis in rats. Eur J Oral Sci 2002;110:125-129.

5. Padgett DA, Marucha PT, Sheridan JF. Restraint stress slows cutaneous wound healing in mice. Brain Behav Immun 1998;12:64-73.

6. Allan SM, Tyrrell PJ, Rothwell NJ. Interleukin-1 and neuronal injury. Nat Rev Immunol 2005;5:629-640.

7. Simi A, Tsakiri N, Wang P, Rothwell NJ. Interleukin-1 and inflammatory neurodegeneration. Biochem Soc Trans 2007;35:1122-1126.
8. de Kloet ER, Joels M, Holsboer F. Stress and the brain: from adaptation to disease. Nat Rev Neurosci 2005;6:463-475.

9. You Z, Luo C, Zhang W, Chen Y, He J, Zhao Q, Zuo $\mathrm{R}$, Wu Y. Pro- and anti-inflammatory cytokines expression in rat's brain and spleen exposed to chronic mild stress: involvement in depression. Behav Brain Res 2011;225:135-141.

10. Musazzi L, Milanese M, Farisello P, Zappettini S, Tardito D, Barbiero VS, Bonifacino T, Mallei A, Baldelli P, Racagni G, Raiteri M, Benfenati F, Bonanno G, Popoli M. Acute stress increases depolarizationevoked glutamate release in the rat prefrontal/frontal cortex: the dampening action of antidepressants. PLoS One 2010;5:e8566.

11. Hardingham GE, Fukunaga $Y$, Bading $H$. Extrasynaptic NMDARs oppose synaptic NMDARs by triggering CREB shut-off and cell death pathways. Nat Neurosci 2002;5:405-414.

12. Samarghandian S, Azimi-Nezhad M, Borji A, Farkhondeh T. Crocus sativus L.(saffron) extract reduces the extent of oxidative stress and proinflammatory state in aged rat kidney. Prog Nutr 2016;18:299-310.

13. Genco RJ, Ho AW, Kopman J, Grossi SG, Dunford RG, Tedesco LA. Models to evaluate the role of stress in periodontal disease. Ann Periodontol 1998;3:288302.

14. Akyol S, Ginis Z, Armutcu F, Ozturk G, Yigitoglu MR, Akyol O. The potential usage of caffeic acid phenethyl ester (CAPE) against chemotherapy-induced and radiotherapy-induced toxicity. Cell Biochem Funct 2012;30:438-443.

15. Gremy O, Benderitter M, Linard C. Caffeic acid phenethyl ester modifies the Th1/Th2 balance in ileal mucosa after gamma-irradiation in the rat by modulating the cytokine pattern. World J Gastroenterol 2006;12:4996-5004.

16. Celik S, Gorur S, Aslantas O, Erdogan S, Ocak S, Hakverdi S. Caffeic acid phenethyl ester suppresses oxidative stress in Escherichia coli-induced pyelonephritis in rats. Mol Cell Biochem 2007;297:131 138.

17. Ha J, Choi H-S, Lee Y, Lee ZH, Kim H-H. Caffeic acid phenethyl ester inhibits osteoclastogenesis by suppressing NFкB and downregulating NFATc1 and cFos. Int Immunopharmacol 2009;9:774-780.

18. Kazancioglu HO, Aksakalli S, Ezirganli S, Birlik M, Esrefoglu M, Acar AH. Effect of caffeic acid phenethyl ester on bone formation in the expanded interpremaxillary suture. Drug Des Devel Ther 2015;9:64836488 .

19. Kazancioglu HO, Bereket MC, Ezirganli S, Aydin MS, Aksakalli S. Effects of caffeic acid phenethyl ester on wound healing in calvarial defects. Acta Odontol Scand 2015;73:21-27.

20. Koltuksuz U, Mutus HM, Kutlu R, Ozyurt H, Cetin S, Karaman A, Gurbuz N, Akyol O, Aydin NE. Effects of caffeic acid phenethyl ester and epidermal growth 
factor on the development of caustic esophageal stricture in rats. J Pediatr Surg 2001;36:1504-1509.

21. Ucan MC, Koparal M, Agacayak S, Gunay A, Ozgoz M, Atilgan S, Yaman F. Influence of caffeic acid phenethyl ester on bone healing in a rat model. J Int Med Res 2013;41:1648-1654.

22. Aguiar JC, Gomes EP, Fonseca-Silva T, Velloso NA, Vieira LT, Fernandes MF, Santos SH, Neto JF, DePaula AM, Guimaraes AL. Fluoxetine reduces periodontal disease progression in a conditioned fear stress model in rats. J Periodontal Res 2013;48:632-637.

23. Gomes EP, Aguiar JC, Fonseca-Silva T, Dias LC, Moura-Boas KP, Roy A, Velloso NA, Rodrigues-Neto JF, De-Paula AM, Guimaraes AL. Diazepam reverses the alveolar bone loss and hippocampal interleukin1 beta and interleukin- 6 enhanced by conditioned fear stress in ligature-induced periodontal disease in rats. J Periodontal Res 2013;48:151-158.

24. Peruzzo DC, Benatti BB, Antunes IB, Andersen ML, Sallum EA, Casati MZ, Nociti FH, Nogueira-Filho GR. Chronic stress may modulate periodontal disease: a study in rats. J Periodontol 2008;79:697-704.

25. Gurkan A, Emingil G, Nizam N, Doganavsargil B, Sezak M, Kutukculer N, Atilla G. Therapeutic efficacy of vasoactive intestinal peptide in escherichia coli lipopolysaccharide-induced experimental periodontitis in rats. J Periodontol 2009;80:1655-1664.

26. Llavaneras A, Ramamurthy NS, Heikkila P, Teronen O, Salo T, Rifkin BR, Ryan ME, Golub LM, Sorsa T. A combination of a chemically modified doxycycline and a bisphosphonate synergistically inhibits endotoxininduced periodontal breakdown in rats. J Periodontol 2001;72:1069-1077.

27. Lutfioglu M, Sakallioglu U, Sakallioglu EE, Baris S, Gurgor P. The impact of dietary induced hyperparathyroidism on healthy and diseased periodontia: an experimental study in rats. J Clin Periodontol 2012;39:264-271.

28. Yilmaz HR, Uz E, Altunbasak A, Sakalli E, Ozcelik N. Anticlastogenic effect of caffeic acid phenethyl ester on cisplatin-induced chromosome aberrations in rat bone marrow cells. Toxicol Ind Health 2010;26:33-37.

29. Esen C, Alkan BA, Kirnap M, Akgul O, Isikoglu S, Erel O. The effects of chronic periodontitis and rheumatoid arthritis on serum and gingival crevicular fluid total antioxidant/oxidant status and oxidative stress index. J Periodontol 2012;83:773-779.

30. Arabaci T, Kermen E, Ozkanlar S, Kose O, Kara A, Kizildag A, Duman SB, Ibisoglu E. Therapeutic Effects of Melatonin on Alveolar Bone Resorption After Experimental Periodontitis in Rats: A Biochemical and Immunohistochemical Study. J Periodontol 2015;86:874-881.

31. Correa MG, Gomes Campos ML, Marques MR, Bovi Ambrosano GM, Casati MZ, Nociti FH, Jr., Sallum EA. Outcome of enamel matrix derivative treatment in the presence of chronic stress: histometric study in rats. $\mathbf{J}$ Periodontol 2014;85:e259-267.

32. Yigit U, Kirzioglu FY, Uguz AC, Naziroglu M, Ozmen O. Is caffeic acid phenethyl ester more protective than doxycycline in experimental periodontitis? Arch Oral Biol 2017;81:61-68.

33. Araujo AA, Souza TO, Moura LM, Brito GA, Aragao KS, Araujo LS, Medeiros CA, Alves MS, Araujo RF, Jr. Effect of telmisartan on levels of IL-1, TNF-alpha, down-regulated COX-2, MMP-2, MMP-9 and RANKL/RANK in an experimental periodontitis model. J Clin Periodontol 2013;40:1104-1111.

34. Wang R-p, Yao Q, Xiao Y-b, Zhu S-b, Yang L, Feng J-m, Li D-z, Li X-1, Wu J-j, Chen J. Toll-like receptor 4/nuclear factor-kappa B pathway is involved in myocardial injury in a rat chronic stress model. Stress 2011;14:567-575.

35. Kose O, Arabaci T, Kara A, Yemenoglu H, Kermen E, Kizildag A, Gedikli S, Ozkanlar S. Effects of Melatonin on Oxidative Stress Index and Alveolar Bone Loss in Diabetic Rats With Periodontitis. J Periodontol 2016;87:e82-90.

36. Samarghandian S, Azimi-Nezhad M, Borji A, Samini M, Farkhondeh T. Protective effects of carnosol against oxidative stress induced brain damage by chronic stress in rats. BMC Complement Altern Med 2017; 17:249-255.

37. Ekuni D, Tomofuji T, Tamaki N, Sanbe T, Azuma T, Yamanaka R, Yamamoto T, Watanabe T. Mechanical stimulation of gingiva reduces plasma $8-\mathrm{OHdG}$ level in rat periodontitis. Arch Oral Biol 2008;53:324-329.

38. Agarwal S, Piesco NP, Johns LP, Riccelli AE. Differential expression of IL-1 beta, TNF-alpha, IL-6, and IL-8 in human monocytes in response to lipopolysaccharides from different microbes. J Dent Res 1995;74:1057-1065.

39. Kose O, Arabaci T, Kizildag A, Erdemci B, Ozkal Eminoglu D, Gedikli S, Ozkanlar S, Zihni M, Albayrak M, Kara A, Kermen E. Melatonin prevents radiationinduced oxidative stress and periodontal tissue breakdown in irradiated rats with experimental periodontitis. J Periodontal Res 2017;52:438-446. 